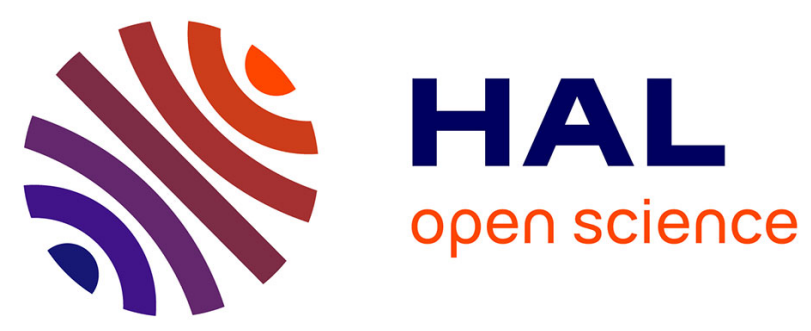

\title{
Solar Electric Motor on Superconducting Bearings: Design and Tests in Liquid Nitrogen
}

Kévin Berger, Fawzi Boufatah, Rafael-Antonio Linares-Lamus, Hocine Menana, Melika Hinaje, Bruno Douine, Jean Lévêque

\section{- To cite this version:}

Kévin Berger, Fawzi Boufatah, Rafael-Antonio Linares-Lamus, Hocine Menana, Melika Hinaje, et al.. Solar Electric Motor on Superconducting Bearings: Design and Tests in Liquid Nitrogen. IEEE Transactions on Applied Superconductivity, 2017, 27 (4), pp.5200505. 10.1109/TASC.2016.2642140 . hal-01398145

\section{HAL Id: hal-01398145 \\ https://hal.science/hal-01398145}

Submitted on 23 Nov 2016

HAL is a multi-disciplinary open access archive for the deposit and dissemination of scientific research documents, whether they are published or not. The documents may come from teaching and research institutions in France or abroad, or from public or private research centers.
L'archive ouverte pluridisciplinaire HAL, est destinée au dépôt et à la diffusion de documents scientifiques de niveau recherche, publiés ou non, émanant des établissements d'enseignement et de recherche français ou étrangers, des laboratoires publics ou privés. 


\title{
Solar Electric Motor on Superconducting Bearings: Design and Tests in Liquid Nitrogen
}

\author{
Kévin Berger, Fawzi Boufatah, \\ Rafael Linares, Hocine Menana, Melika Hinaje, Bruno Douine, and Jean Lévêque
}

\begin{abstract}
The concept of the motor, described here, has been presented for the first time in 1959. It allows to convert light energy into mechanical energy, without the need of any brushes or other power electronics. An original improvement that we have made to this structure concerns the superconducting suspension which tends to limit frictions and ensures natural stability of the rotor. The second major novelty is that we have designed the entire motor for operating in liquid nitrogen. The motor structure is detailed in this article, including the electromagnetic design, the electrical and mechanical equations. Two different configurations of superconducting bearings are studied in order to make levitate the rotors. Finally, for the designed motors, only $10 \%$ of the installed onboard power is converted into mechanical power. All the experimental results, especially the speed of the motor, are consistent with the estimated values by the model.
\end{abstract}

Index Terms-Levitation, liquid nitrogen, Mendocino motor, motor design, solar electric motor, superconducting bearing.

\section{INTRODUCTION}

$\mathrm{T}$ HERE ARE some types of electric engines whose industrial future is unclear but deserve nevertheless to be studied for specific applications or simply by scientific curiosity. The motor studied in this work belongs to this category of engines for several reasons. Indeed, solar electric motors also called "Photovoltaic motors" are little known as conversion systems. The operating principle is that of a DC motor where the major disadvantage, i.e. the slip rings no longer exist. The armature windings are fed by rotary photovoltaic cells optically commuted when the solar cells attached to the rotor are switching from high brightness to low brightness. This allows to convert light energy into mechanical energy, without the need of any brushes or other power electronics.

The concept has been described for the first time in 1959 by W. A. Marrison [1]. It has been patented under various forms [1]-[8] but the scientific literature is restricted [9]-[11].

A magnetic suspension of the rotor was added later by Larry Spring in 1994 [12], and because his experimental laboratory was located in the Mendocino coast in California, the engine was named "Larry Spring's Magnetic Levitation Mendocino Brushless Solar Motor" more commonly J. Lévêque are with the University of Lorraine, GREEN, Group of Research in Electrical Engineering of Nancy - EA 4366, Faculté des Sciences et Technologies, BP 70239, 54506Vandoeuvre-lès-Nancy Cedex, France (email: name.surname@univ-lorraine.fr).
"Mendocino Motor."

An original improvement that we have made to this structure concerns the superconducting suspension which tends to limit frictions and ensures natural stability of the rotor. The second major novelty is that we have designed the entire motor for operating in liquid nitrogen LN2.

A description of the structure of the motor is first given, which will be followed by the developed models to perform the design of the motor. A section will be dedicated to the solar cells description and their characterization. Finally, two configurations of superconducting bearings are presented and also the results of the realized prototypes functioning at ambient air or in liquid nitrogen.

\section{Motor StRUCtURE AND DeSIGN}

\section{A. Description}

The motor structure is illustrated in Fig.1. The stator (inductor) consists of a permanent magnet at the base, which creates a fixed magnetic field. The rotor (armature) is composed of 2 coils powered by 4 flat photovoltaic cells. The rotor is held in levitation using bearings that are an association of a Permanent Magnet (PM) with a High Temperature Superconducting (HTS) bulk cooled by liquid nitrogen.

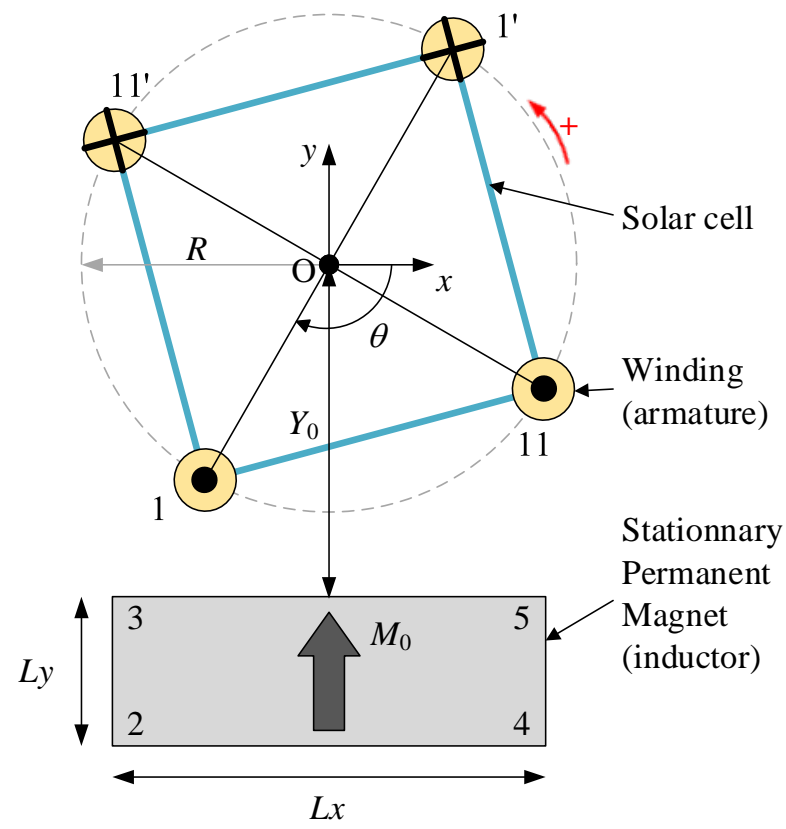

Fig. 1. Illustration of the machine with the labels used to identify the dimensions. The inductor, a Permanent Magnet (PM) delimited by its corners $\{2,3,4,5\}$. The armature is composed of 2 coils, sketched as 4 wires labeled $\{1,1$ ', 11, 11'\}. 


\section{B. Electromagnetic Design}

A 2D simplified model of the machine is shown in Fig. 1. The magnetic vector potential $A_{z}$, produced by a magnet considered as infinitely long along the $z$ axis, on the conductor labeled " 1 " of the armature of the machine is given by:

$$
A_{z}=\frac{\mu_{0} M_{0}}{4 \pi}\left(\begin{array}{l}
\Delta y_{13} \ln \left(\left(\Delta y_{13}{ }^{2}+\Delta x_{13}{ }^{2}\right) \cdot\left(\Delta y_{15}{ }^{2}+\Delta x_{15}{ }^{2}\right)^{-1}\right) \\
-\Delta y_{12} \ln \left(\left(\Delta y_{12}{ }^{2}+\Delta x_{12}{ }^{2}\right) \cdot\left(\Delta y_{14}{ }^{2}+\Delta x_{14}{ }^{2}\right)^{-1}\right) \\
+2 \Delta x_{13} \arctan \left(\frac{\Delta y_{13}}{\Delta x_{13}}\right)-2 \Delta x_{15} \arctan \left(\frac{\Delta y_{15}}{\Delta x_{15}}\right) \\
-2 \Delta x_{12} \arctan \left(\frac{\Delta y_{12}}{\Delta x_{12}}\right)+2 \Delta x_{14} \arctan \left(\frac{\Delta y_{14}}{\Delta x_{14}}\right)
\end{array}\right)
$$

With $\Delta x_{i j}=x_{i}-x_{j}$ and $\Delta y_{i j}=y_{i}-y_{j}, \quad x_{i}$ and $y_{i}$ are the coordinates of the point denoted $i$ in the plan $x \mathrm{O} y$, and $M_{0}$ is the magnetization of the PM. The $B_{x}$ and $B_{y}$ components of the magnetic flux density can be determined from (1) and are shown in [13]. The self-inductance $L$ of the coils is given by the equation (24) of [14].

The currents flowing in the wires $\{1,11\}$ depend on the angle of incidence of the light source on the solar cell which feeds them, and therefore, on the position of the rotor $\theta$. The currents flowing in the wires $\left\{1^{\prime}, 11^{\prime}\right\}$ are exactly opposite to those in $\{1,11\}$. Knowing the current in each wire depending on the position of the rotor, the torque can thus be analytically calculated.

\section{Electrical and Mechanical Equations}

A sketch of one coil connected to its 2 corresponding solar cells is shown on Fig. 2. Thus, from the electric diagram of the armature shown in Fig. 3, we can write the voltage across each coil $\{1,1$ ' $\},\{11,11$ ' $\}$ in its conventional form for a DC motor:

$$
u(t)=r i(t)+L \frac{d i(t)}{d t}+e(t) \text { with } e(t)=k_{\omega} \omega(t)
$$

and where the parameters $r, L$ and $k_{\omega}$ can all be calculated analytically. The mechanical equation involves a load torque that corresponds to the friction between the rotor and the environment:

$$
J \frac{d \omega(t)}{d t}=\Gamma_{\text {motor }}(t)-\Gamma_{\text {load }}(t) \text { with } \Gamma_{\text {motor }}(t)=k_{\omega} \omega(t) i(t)
$$

And $J$ the moment of inertia of the rotor. $\Gamma_{\text {motor }}$ and $\Gamma_{\text {load }}$ are the torques produced by the motor and the load respectively.

\section{Simulink Model}

Because of the multiphysic and nonlinear nature of the system, we choose to implement the whole model in Simulink. The whole diagram is shown in Fig. 4 with some typical waveforms as illustrations. The block "CEMF calculation" is used to calculate the Counter-ElectroMotive Force $e(t)$ on the armature using the dimensions of the system, the number of

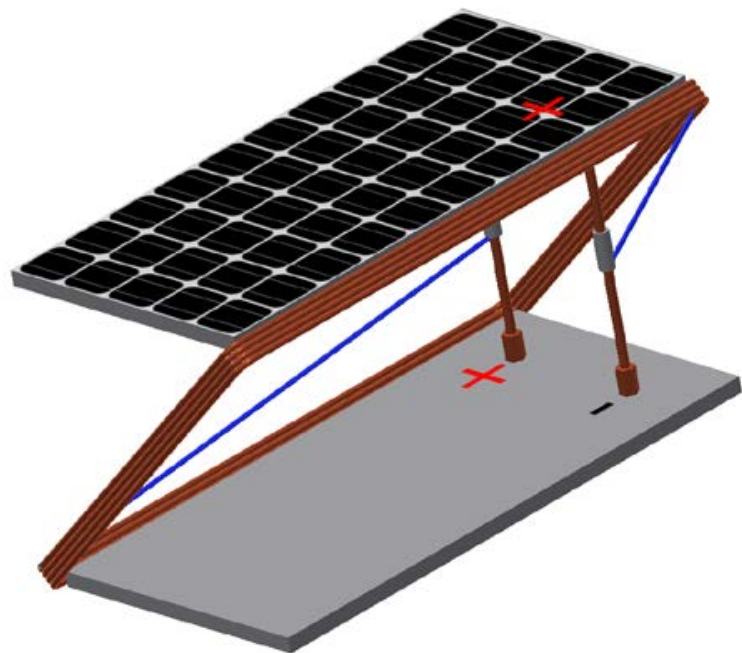

Fig. 2. Sketch of one coil connected to its 2 corresponding solar cells. The other coil is the same, but rotated by $90^{\circ}$ around the $z$-axis.

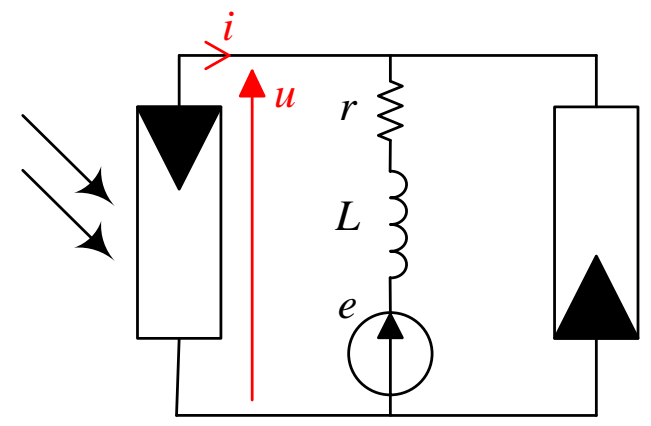

Fig. 3. Electric diagram of the armature with an illuminated solar cell on the left.

turns $N$ and the position of the rotor $\theta$. The number of turns $N$ is also an input of the system that is chosen in order to optimize the mechanical power produce by the motor. The waveform of the CEMF on one coil with the corresponding illumination "Illum. 1" of one solar cell is shown in Fig. 4 (b). The "Illuminance block" estimates the illuminance submitted to the solar cells from the position of the rotor. Fig. 4 (c) shows the illumination of two solar cells on both sides of the rotor vs time. The "Electrical equation" block gives the current as an output considering the electrical circuit of Fig. 3 with the estimated $I-V$ curves of the solar cells. Then, the torque "Torque 1" on one coil can be calculated and the torque "Torque 2" on the second coil is deduced by phase shifting "Torque 1 " by $\pi /(2 \omega)$. Finally, the mechanical equation (3) is solved using the load torque produced on the whole rotor.

\section{E. Parameters used}

By using basic relations of fluid dynamics and some typical sizes of solar cells shown in Table I, a no-load torque $\Gamma_{\text {load }}$ per unit length around $6.7 \times 10^{-6} \omega^{2} \mathrm{~N}$ at ambient air has been considered and a moment of inertia $J$ per unit length of $41.7 \times 10^{-5} \mathrm{~kg} \cdot \mathrm{m}$. In liquid nitrogen, the no-load torque per unit length increases around $792 \times 10^{-6} \omega^{2} \mathrm{~N}$ due to the increase of the fluid viscosity. 

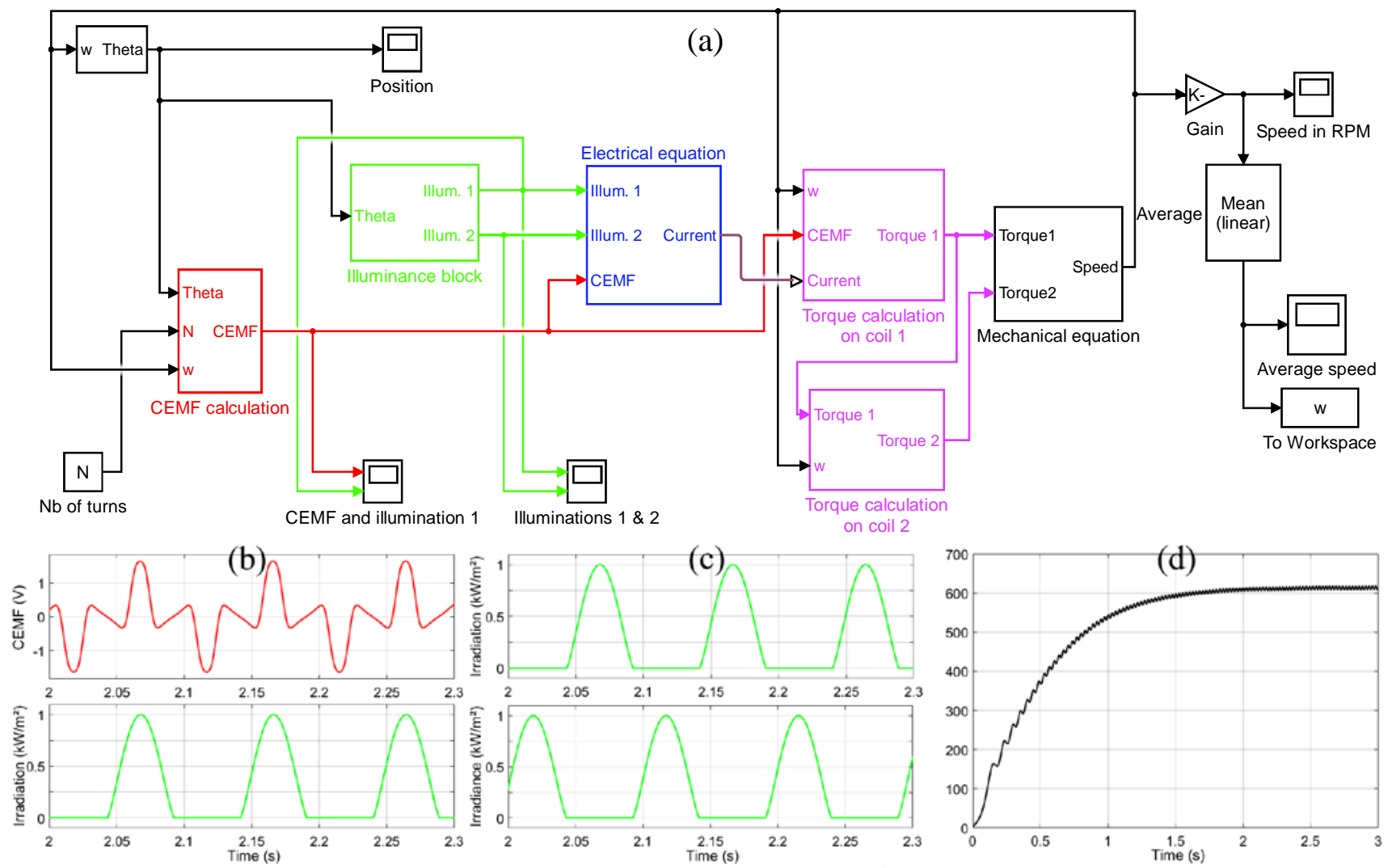

Fig. 4. (a) Simulink diagram of the whole motor. (b) Illustration of the counter-electromotive force on "coil 1" (up) with the corresponding illumination "Illum. 1" of one solar cell. (c) Illumination of two solar cells on both sides of the rotor vs. time. (d) Example of temporal evolution of the speed of the rotor.

The stator is composed of one $\mathrm{NdFeB}$ permanent magnet, using $2 \times \mathrm{Q}-50-50-12.5-\mathrm{N}$ from [15], which leads to an overall dimensions of $100 \mathrm{~mm} \times 50 \mathrm{~mm} \times 12.5 \mathrm{~mm}(L z \times L x \times L y)$. The material is referred as N35 with a remanent induction of $1.21 \mathrm{~T}$.

Solar cells of $2 \mathrm{~V}-380 \mathrm{~mA}$ were chosen, see Table I. The optimal rotor designed for operating at ambient air is made of 2 winding coils of 35 turns each, using an enameled copper wire of $0.7 \mathrm{~mm}$ of diameter. The rotor for being used in liquid nitrogen is made of 2 winding coils of 230 turns each, with a wire of $0.4 \mathrm{~mm}$ of diameter. These choices lead to some cuboid rotors whose overall dimensions are $85 \mathrm{~mm} \times 85 \mathrm{~mm}$ of square section and an active length of $130 \mathrm{~mm}$.

\section{SOLAR CELLS}

\section{A. Description}

Standard polycrystalline solar cells have been bought from [16]. The dimensions and the characteristics of the solar cells

TABLE I

DIMENSIONS AND CHARACTERISTICS OF THE SOLAR CELLS

\begin{tabular}{cccc}
\hline \hline $\begin{array}{c}\text { Dimensions } \\
(\mathrm{mm} \times \mathrm{mm} \times \mathrm{mm})\end{array}$ & Voltage $(\mathrm{V})$ & Current $(\mathrm{mA})$ & Power $(\mathrm{mW})$ \\
\hline $120 \times 60 \times 2$ & 6.00 & 150 & 900 \\
$115 \times 60 \times 2$ & 2.00 & 380 & 760 \\
$120 \times 60 \times 2$ & 1.00 & 850 & 850 \\
$120 \times 60 \times 2$ & 0.50 & 1700 & 850 \\
\hline \hline
\end{tabular}

This table summarized the bought solar cells. The solar cell of $1 \mathrm{~V}-$ $850 \mathrm{~mA}$ is made by using 4 cells $0.5 \mathrm{~V}-425 \mathrm{~mA}$ (2 in parallel and 2 in series). The solar cell of $0.5 \mathrm{~V}-1700 \mathrm{~mA}$ is made by using 4 cells $0.5 \mathrm{~V}-$ $425 \mathrm{~mA}$ in parallel.
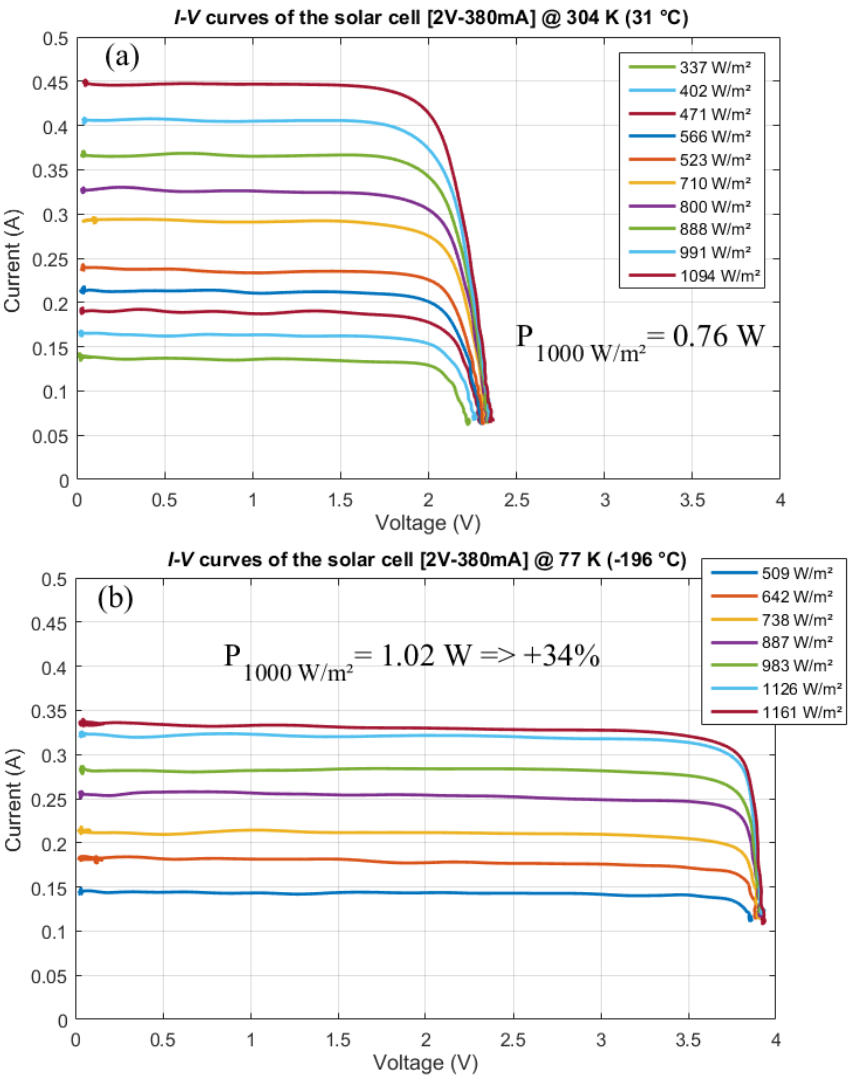

Fig. 5. $I-V$ curves of the solar cell $2 \mathrm{~V}-380 \mathrm{~mA}$ for different positions from the light source, i.e. for different irradiances: (a) at ambient air temperature $304 \mathrm{~K}$ and (b) in liquid nitrogen at $77 \mathrm{~K}$. The delivered power by the solar cell has increased of $+34 \%$ for the same irradiance of $1000 \mathrm{~W} / \mathrm{m}^{2}$. 


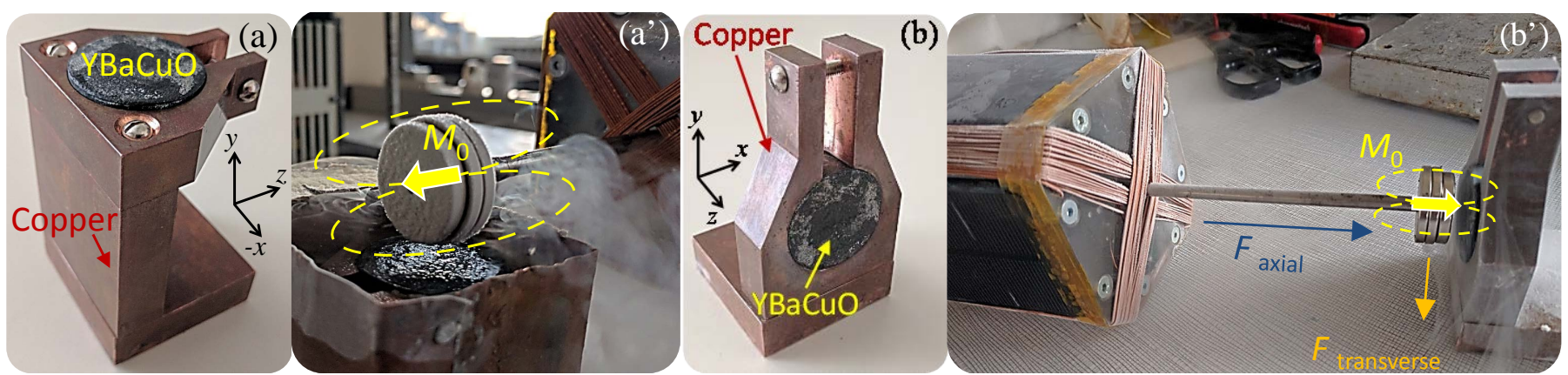

Fig. 6. Pictures of the superconducting bearings. (a) Horizontal configuration: YBaCuO pellet of $30 \mathrm{~mm}$ of diameter and $10 \mathrm{~mm}$ in height placed in a copper structure. (a') Levitation of the rotor in the horizontal configuration with a PM at the end of the shaft. (b) Vertical configuration: the YBaCuO pellet is the same. (b') Levitation of the rotor in the vertical configuration of the bearing. A part of the rotor is visible on this picture.

are summarized in Table I. Each solar cell leads us to equivalent estimated maximum speeds of the rotor around $660 \pm 10 \mathrm{rpm}$ but with different optimal number of turns. In fact, higher is the solar cell voltage higher is the optimal number of turns. Moreover, if the cross section of the winding wire is proportional to the solar cell current, the weight of the windings is almost the same for all the solar cells given in Table I.

\section{B. I-V Curves}

$I-V$ curves of the solar cells $2 \mathrm{~V}-380 \mathrm{~mA}$ has been experimentally obtained at ambient air and also in liquid nitrogen. It is well known that the temperature can affect the solar cell characteristics, e.g. the power provided by the cell decreases with increasing temperature. On the contrary, a decrease of the temperature is also beneficial for the performances. Excepted the reference [17] which addresses solar cell experiments down to $140 \mathrm{~K}$, we have not been able to find some pertinent literatures that deal with solar cells in liquid nitrogen, at $77 \mathrm{~K}$.

Since we aim to make the motor operates in LN2, an experimental bench was built to characterize the solar cell from the room temperature to the LN2 temperature. The obtained $I-V$ curves at $304 \mathrm{~K}$ and $77 \mathrm{~K}$ of the solar cell $2 \mathrm{~V}-$ $380 \mathrm{~mA}$ are presented in Fig. 5. The experimental bench allows to vary the distance between the solar cell and the light source at a constant temperature. Then, the load connected to the solar cell were varied in order to obtain the $I-V$ curves at different illuminances. The delivered power by the solar cell at $1000 \mathrm{~W} / \mathrm{m}^{2}$ has increased of $+34 \%$, from $0.76 \mathrm{~W}$ up to $1.02 \mathrm{~W}$. The increase of the maximum power of solar cells with temperature decrease is already know [18]. However, the authors were not able to find such experimental $I-V$ curves of solar cells immersed in LN2.

\section{SuPERCONDUCTING BEARINGS AND FINAL TESTS}

There are many studies describing the performance of superconducting levitation systems or bearings [13], [19][29]. Most of the studies concerns 2D electromagnetic problems, axisymmetric or infinitely long. Indeed, 3D problems are very complex to solve and required a large amount of memory and are time consuming. In the study detailed here, the problem is 3D by nature, for both the vertical and the horizontal configuration. We aimed to be pragmatic, and only experimental measurements have been made because we know from the literature that a weight of $1 \mathrm{~kg}$ is bearable with superconducting bearings. Two $\mathrm{YBaCuO}$ pellets from [30] have been used for the bearings. The diameter is of $30 \mathrm{~mm}$ and the height is almost $12 \mathrm{~mm}$. The $\mathrm{NdFeB}$ permanent magnets used to interact with the HTS bulks is of $25 \mathrm{~mm}$ in diameter and an overall height of $10 \mathrm{~mm}$.

We have built two configurations of bearings shown in Fig. 6. Both are made with copper blocks in order to thermalize the $\mathrm{YBaCuO}$ pellet independently of the liquid nitrogen level, Fig. 6 (a) and (b). The blocs are then placed in a copper casket in order to fill the empty volume with liquid nitrogen, see Fig. 6 (a'). The horizontal configuration shown in Fig. 6 (a) allows the shaft of the rotor to levitate above the HTS bulk, Fig. 6 (a'). On the contrary, the vertical configuration, shown in Fig. 6 (b), permits to align the shaft with the axis of the HTS bulk, Fig. 6 (b'). Both configurations have been tested using an electronic scale for the weight measurements. For one single bearing of the horizontal configuration, Fig. 6 (a)-(a'), the mass supported along the $y$ axis strongly depends on the distance between the HTS bulk and the PM during the field cooling process: $1.5 \mathrm{~kg}$ for a distance of $1 \mathrm{~mm}, 2 \mathrm{~mm}-1.8 \mathrm{~kg}, 3 \mathrm{~mm}-2.4 \mathrm{~kg}, 4 \mathrm{~mm}-$ $3 \mathrm{~kg}$. Higher is the distance used for the field cooling, lower is the stability of the system, and particularly the stability in the $x$-axis. Consequently, the smallest distance that allows the levitation of rotor has been chosen, i.e. around $1 \mathrm{~mm}$. For the vertical configuration, Fig. 6 (b)-(b'), due to the thickness of the wall of the copper casket, the smallest distance possible for the field cooling process of the HTS is $0.8 \mathrm{~mm}$. In that position, the maximum weight that can be supported by one bearing of the vertical configuration is $0.7 \mathrm{~kg}$.

The weight of the whole rotor, operating at ambient air, is 475 g, including: 4 solar cells $(4 \times 30$ g), 2 coils $(2 \times 50$ g), the mechanical structure (135 g) in Plexiglas to support the solar cells and the windings, the shaft with the $\mathrm{PM}$ at its ends (120 g). The rotor designed for LN2 weighs $955 \mathrm{~g}$ due to the increase of the number of turns. Therefore, both configurations of bearings can support the built rotors. However, the horizontal configuration leads to a poor stability due to the unbalanced rotors.

Both rotors have been tested successfully at ambient air with the vertical configuration of superconducting bearings at $900 \mathrm{rpm}$ [31] and $1350 \mathrm{rpm}$ [32], with the horizontal 
configurations at $700 \mathrm{rpm}$ [33], and in liquid nitrogen at $75 \mathrm{rpm}$ [34] and $190 \mathrm{rpm}$ by adding a cylinder around the cubic rotor [35]. The mechanical power produced is about $0.27 \mathrm{~W}$ for the rotor designed at ambient air and $0.33 \mathrm{~W}$ for the one dedicated to the LN2. These values have to be compared to the onboard power of the solar cells of approximately $2.7 \mathrm{~W}$. That also means that $10 \%$ of the installed onboard power is converted into mechanical power.

\section{CONCLUSION}

The study of a solar motor on superconducting bearings has been achieved for the first time. Several aspects of the design have been detailed in this work. All the experimental results, especially the speed of the motor, are consistent with the estimated values by the model. Future works are ongoing on an onboard measurement system for acquiring the voltage and the current of the stator. A deeper study will be also conducted on the potential of such motor as a pump in liquid nitrogen, for industrial or research applications, i.e. for higher mechanical powers.

\section{ACKNOWLEDGMENT}

The authors would like to thank Isabelle Schwenker for its help during the setup of the experimental parts. We are also grateful to Mariusz Stepien and Boguslaw Grzesik for organizing, in 2014, the visit of the Silesian University of Technology where we have seen such a solar motor for the first time.

\section{REFERENCES}

[1] W. A. Marrison, Apparatus for converting radiant energy to electromechanical energy. Patent US2919358, 1959.

[2] A. Coty, Automatically switched photovoltaic motor. Patent WO2010082007A3, 2011.

[3] D. M. Chapin, C. S. Fuller, and G. L. Pearson, Solar energy converting apparatus. Patent US2780765, 1957.

[4] H. E. Hall, Solar motor. Patent US3296469, 1967.

[5] H. Izawa, Solar energy motor. Patent US4751413, 1988.

[6] Y. Nakamats, Apparatus for converting radiant energy such as light or heat directly into turning force. Patent US4634343, 1987.

[7] B. Sepp, Rotating advertising device. Patent US3325930, 1967.

[8] G. J. Shea, Solar energy magnetic resonance motor. Patent US5408167, 1995.

[9] J. Bobitski and D. Iwiński, "Investigation of photoelectric motor with stationary axial diaphragm static and dynamic characteristics," Opto Electronics Review, vol. Vol. 12, No. 1, pp. 85-90, 2004.

[10] L. Quéval, A. Coty, L. Vido, R. Gottkehaskamp, and B. Multon, "Photovoltaic switched reluctance motor modeling and simulation," in 2015 IEEE 15th International Conference on Environment and Electrical Engineering (EEEIC), 2015, pp. 2171-2176.

[11] L. Quéval, L. Vido, A. Coty, and B. Multon, "Photovoltaic motors review, comparison and switched reluctance motor prototype," in 2015 Tenth International Conference on Ecological Vehicles and Renewable Energies (EVER), 2015, pp. 1-8.

[12] L. Spring, "Larryspring School of Common Sense Physics." [Online]. Available: http://www.larryspring.com/sub06_motors.html. [Accessed: 01-May-2016].

[13] F. Sass, G. G. Sotelo, R. de A. Junior, and F. Sirois, "H-formulation for simulating levitation forces acting on HTS bulks and stacks of 2G coated conductors," Supercond. Sci. Technol., vol. 28, no. 12, p. 125012, 2015

[14] E. B. Rosa, The self and mutual inductances of linear conductors. US Department of Commerce and Labor, Bureau of Standards, 1908.
[15] "Buy strong neodymium magnets online - supermagnete.fr." [Online]. Available: https://www.supermagnete.fr/eng/. [Accessed: 01-May2016].

[16] "La Boutique Solaire.” [Online]. Available: http://www.boutiquesolaire.com/catalog/index.php?cPath=33_130. [Accessed: 01-May-2016].

[17] C. H. Liebert and R. E. Hart, Solar-cell performance at low temperatures and simulated solar intensities. National Aeronautics and Space Administration, 1969.

[18] PVeducation.org, "Effect of Temperature on Solar Cells." [Online]. Available: $\quad$ http://www.pveducation.org/pvcdrom/solar-celloperation/effect-of-temperature. [Accessed: 16-Nov-2016].

[19] D. H. N. Dias et al., "Application of textured YBCO bulks with artificial holes for superconducting magnetic bearing," Supercond. Sci. Technol., vol. 28, no. 7, p. 75005, 2015.

[20] T. Matsumura, Y. Sakurai, H. Kataza, S. Utsunomiya, and R. Yamamoto, "Magnetically coupled gear based drive mechanism for contactless continuous rotation using superconducting magnetic bearing below $10 \mathrm{~K}$," Physica C: Superconductivity and its Applications.

[21] K. Matsunaga, M. Tomita, N. Yamachi, K. Iida, J. Yoshioka, and M. Murakami, "YBCO bulk of the superconducting bearing for a $10 \mathrm{kWh}$ flywheel,” Supercond. Sci. Technol., vol. 15, no. 5, p. 842, 2002.

[22] S. Sivrioglu and K. Nonami, "Active permanent magnet support for a superconducting magnetic-bearing flywheel rotor," IEEE Transactions on Applied Superconductivity, vol. 10, no. 4, pp. 1673-1677, Dec. 2000.

[23] M. Strasik et al., "Design, Fabrication, and Test of a 5-kWh/100-kW Flywheel Energy Storage Utilizing a High-Temperature Superconducting Bearing," IEEE Transactions on Applied Superconductivity, vol. 17, no. 2, pp. 2133-2137, Jun. 2007.

[24] N. D. Valle, A. Sanchez, E. Pardo, C. Navau, and D.-X. Chen, "Enhanced stability by field cooling in superconducting levitation with translational symmetry,” Applied Physics Letters, vol. 91, no. 11, p. 112507, Sep. 2007

[25] W. M. Yang et al., "The effect of magnet configurations on the levitation force of melt processed YBCO bulk superconductors," Physica C: Superconductivity, vol. 354, no. 1-4, pp. 5-12, May 2001.

[26] C.-Q. Ye, G.-T. Ma, K. Liu, and J.-S. Wang, "Observation of the Field, Current and Force Distributions in an Optimized Superconducting Levitation with Translational Symmetry," J Low Temp Phys, pp. 1-15, Aug. 2016.

[27] F. C. Moon, Superconducting Levitation: Applications to Bearing and Magnetic Transportation. John Wiley \& Sons, 2008.

[28] H. Teshima, M. Morita, and M. Hashimoto, "Comparison of the levitation forces of melt-processed $\mathrm{YBaCuO}$ superconductors for different magnets," Physica C: Superconductivity, vol. 269, no. 1, pp. 15-21, Sep. 1996.

[29] M. Murakami et al., "Large Levitation Force due to Flux Pinning in YBaCuO Superconductors Fabricated by Melt-Powder-Melt-Growth Process," Japanese Journal of Applied Physics, vol. 29, no. Part 2, No. 11, pp. L1991-L1994, Nov. 1990.

[30] F. Werfel, "Adelwitz Technologiezentrum GmbH," ATZ. [Online]. Available: http://www.atz-gmbh.com/. [Accessed: 11-May-2016].

[31] K. Berger and F. Boufatah, "Solar Electric Motor on Superconducting Bearings - Vertical Configuration - 900 rpm," Zenodo, http://doi.org/10.5281/zenodo.154013, 2016.

[32] K. Berger and F. Boufatah, "Solar Electric Motor on Superconducting Bearings - Vertical Configuration - 1350 rpm," Zenodo, http://doi.org/10.5281/zenodo.154074, 2016.

[33] K. Berger and F. Boufatah, "Solar Electric Motor on Superconducting Bearings - Horizontal Configuration - 700 rpm," Zenodo, http://doi.org/10.5281/zenodo.154079, 2016.

[34] K. Berger and F. Boufatah, "Solar Electric Motor on Superconducting Bearings in Liquid Nitrogen with Propeller - Vertical Configuration - 75 rpm,” Zenodo, http://doi.org/10.5281/zenodo.154095, 2016.

[35] K. Berger and F. Boufatah, "Solar Electric Motor on Superconducting Bearings in Liquid Nitrogen - Vertical Configuration - 190 rpm," Zenodo, http://doi.org/10.5281/zenodo.154096, 2016. 